\title{
Practitioner perspectives on using nonnative plants for revegetation
}

by Elise Gornish, Elizabeth Brusati and Douglas W. Johnson

Restoration practitioners use both native and nonnative plant species for revegetation projects. Typically, when rehabilitating damaged working lands, more practitioners consider nonnative plants; while those working to restore habitat have focused on native plants. But this may be shifting. Novel ecosystems (non-analog communities) are commonly being discussed in academic circles, while practical factors such as affordability and availability of natives and the need for more drought tolerant species to accommodate climate change may be making nonnative species attractive to land managers. To better understand the current use of nonnatives for revegetation, we surveyed 192 California restoration stakeholders who worked in a variety of habitats. A large portion (42\%) of them considered nonnatives for their projects, and of survey respondents who did not use nonnatives in vegetation rehabilitation, almost half indicated that they would consider them in the future. Across habitats, the dominant value of nonnatives for vegetation rehabilitation was found to be erosion control, and many respondents noted the high cost and unavailability of natives as important drivers of nonnative use in revegetation projects. Moreover, $37 \%$ of respondents noted they had changed their opinion or use of nonnatives in response to climate change.

$\mathrm{R}$ evegetation is a key restoration technique to address environmental damage and increase the ecological value of degraded habitat. It involves the active re-establishment of plant communities through seeding and planting, and is undertaken usually in response to a natural disturbance, such as wildfire, or another restoration activity such as the removal of invasive plants.

Online: https://doi.org/10.3733/ca.2016a0013

Published online September 7, 2016

A recent survey sheds light on how California's land management community views the use of nonnative species for revegetation projects. Here, author Elise Gornish surveys restoration plots in Yolo County.
The design and deployment of effective revegetation requires a practitioner to set project goals, choose plant species and determine methods to reach the desired final state for a site. Species selection is important because plants can modify the physical attributes of a site, land use, community composition and invasive plant species dominance (e.g., Meli et al. 2014).

Often, a fundamental requirement of a candidate plant species for revegetation is its classification as a native species. Native plants facilitate plant community trajectories toward a reference site condition, augment nutrient cycling, enhance wildlife habitat and reverse biodiversity loss (e.g., Bullock et al. 2011). In addition to the clear value of using native species to re-establish plant communities, however, there are several limitations of a natives-only requirement for revegetation projects. For example, native plant materials can be financially prohibitive (sometimes costing more than $\$ 1,000$ per acre; Gornish 2015) and difficult to acquire.

The high cost of plant materials is one of the leading obstacles to effective revegetation nationwide (Brodt et al. 2009; Clewell and Rieger 1997; Stanturf et al. 2001). The exclusive use of native plants 
can also restrict revegetation success because natives may not compete well with extant invasive species (Davies et al. 2010; Herget et al. 2015) and they may not establish as readily as nonnative species (Monsen 2004).

For the goals of some revegetation projects, nonnative plants provide greater management value than natives (e.g.; D'Antonio and Meyerson 2002; SER 2004). For example, nonnative species might be competitively dominant to local weeds and, once seeded, prevent the establishment and spread of, and damage caused by, aggressive invasive plant species (Davies et al. 2010; Davies et al. 2015).

The rapid establishment rate of nonnatives is useful for erosion control in high-stress environments where soil destabilization is typical or revegetating landscapes exposed to intense wildfire (Pyke et al. 2013). The presence and persistence of nonnatives might also be facilitated more by changing environmental conditions than natives through, for example, altered introduction mechanisms (Hellmann et al. 2008). This would allow practitioners to accommodate the continuing effects of climate change on degraded habitat (Stromberg and Griffin 1996; Vasey and Holl 2007).

As expected, there is heated debate as to the overall environmental benefit and ecological ethics associated with using nonnatives for revegetation projects (Davison and Smith 1996; Pyke et al. 2013). Researchers acknowledge that many ecological habitats cannot return to the traditional native reference states that often form the basis of restoration project designs (e.g., Egan and Howell 2001). These habitats, termed "novel ecosystems" (Hobbs et al. 2006; Hobbs et al. 2009), contain novel species assemblages, interactions and functions (often as a result of climate change) and may require atypical approaches to revegetation. As a result, many practitioners now appear to be willing to consider nonnative species in revegetation projects (Carroll 2011; Eviner et al. 2012; Ewel and Putz 2004; Rodriguez 2006).

In California, where over 1,500 nonnative species have become naturalized or

\section{An in-progress restoration experiment in}

Monterey County. The right half of the fenced plot was sprayed to reduce invasive Russian thistle (tumbleweed). invasive in agricultural and natural areas (DiTomaso and Healy 2007), discussions concerning the potential role of nonnatives for revegetation are particularly intense due to the well-recognized ecological and economic impacts of weedy species. For example, major parts of the intermountain region within and adjacent to California are largely degraded from historic overgrazing and heavily infested by the aggressive annual grass Bromus tectorum (downy brome, or cheatgrass). Although revegetation attempts using native-only species have been longstanding, competitive pressure from downy brome, combined with low moisture availability in the region, has hindered rehabilitation efforts. In response, practitioners have employed nonnative species such as crested wheatgrass (Agropyron cristatum and $A$. desertorum), which have demonstrated great capacity to exclude downy brome and provide adequate ground cover (Asay and Johnson 1983).

These practices have elicited significant controversy. There are those who value the ecosystem services provided by crested wheatgrass and those who want to improve habitat using only native vegetation. The debate is ongoing, as are the different kinds of approaches: some practitioners in the intermountain region continue to use crested wheatgrass for revegetation, and others work to restore planted crested wheatgrass stands to native plant communities (Davies et al. 2013).

Given that approaches to revegetation may be shifting, we wanted to develop an understanding of how California's diverse land management community currently considers nonnative species for ecological revegetation efforts. This basic information will be helpful as a foundation for further discussing the potential role of nonnatives for revegetation (Kondolf et al. 2007).

\section{Survey of land managers}

We conducted a survey to assess California land managers' decision-making strategies involving the use of nonnative plants in revegetation projects. Our goal was to answer three general questions: (1) Across habitat types and organization types, what percentage of individuals implementing revegetation in California use nonnative species? (2) What are the motivations driving the use of nonnative species for revegetation? (3) How does climate change mediate considerations of nonnative species use in revegetation projects?

We had several expectations for survey outcomes. First, we predicted that at least half of the individuals surveyed would consider nonnative species for revegetation projects. We expected this because the well-known difficulties in successfully re-establishing native plant communities in California (e.g., Allen et al. 2005; Stylinski and Allen 1999) can motivate practitioners to try less conventional revegetation approaches. Second, since government agencies can sometimes be slower to adopt new approaches, we predicted that individuals from federal, state and county agencies would be less likely to use nonnatives for revegetation projects

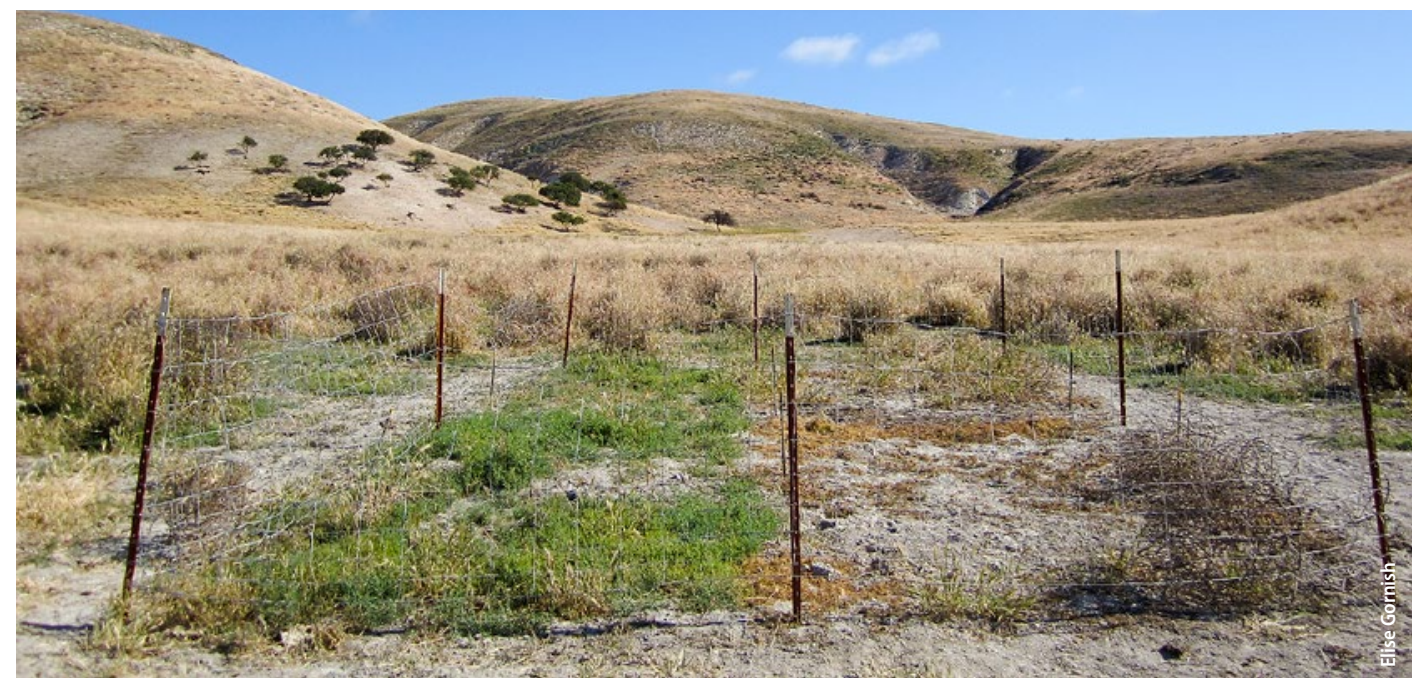


than individuals from nongovernmental organizations (NGOs). We expected erosion control to be the most common motivation for using nonnatives in revegetation projects. Maintaining ground cover to arrest topsoil loss and maintain belowground moisture is one of the most critical components of landscape revegetation - an imperative highlighted by the Society for Ecological Restoration, which advocates for the use of nonnatives, when necessary, to provide ground cover early in the revegetation effort. Finally, many of the underlying principles of ecological revegetation, including the availability of an intact native reference site, and the appropriateness of locally adapted native species, become more complicated to apply when operating within a climate change scenario (Harris et al. 2006). As a result, we expected that a majority of revegetation stakeholders would reconsider attitudes or practices related to the use of nonnative species for revegetation in light of climate change.

\section{Survey development}

We conducted an electronic survey of land managers, restoration consultants and others involved in revegetation in California. Results from an informal pre-survey and interviews with land managers in 2012 were used to refine survey questions. The online survey (created using SurveyMonkey) consisted of 10, mostly multiple-choice questions with space for respondents to include additional comments (table 1 ). The survey was deliberately short, in an attempt to increase participation.

Questions investigated the habitat types in which respondents worked, whether they had used nonnative species, the purpose for which the species were used and whether practices were changing in response to climate change. Questions were posed with reference to restoration, with respondents using their own interpretation of that term.

The survey link was distributed by email in August 2015 to 321 contacts identified by the authors as active in the field of vegetation management. These contacts were composed of land managers drawn from the membership list of the nonprofit California Invasive Plant Council. The survey was also posted to the LinkedIn groups of the California Society for

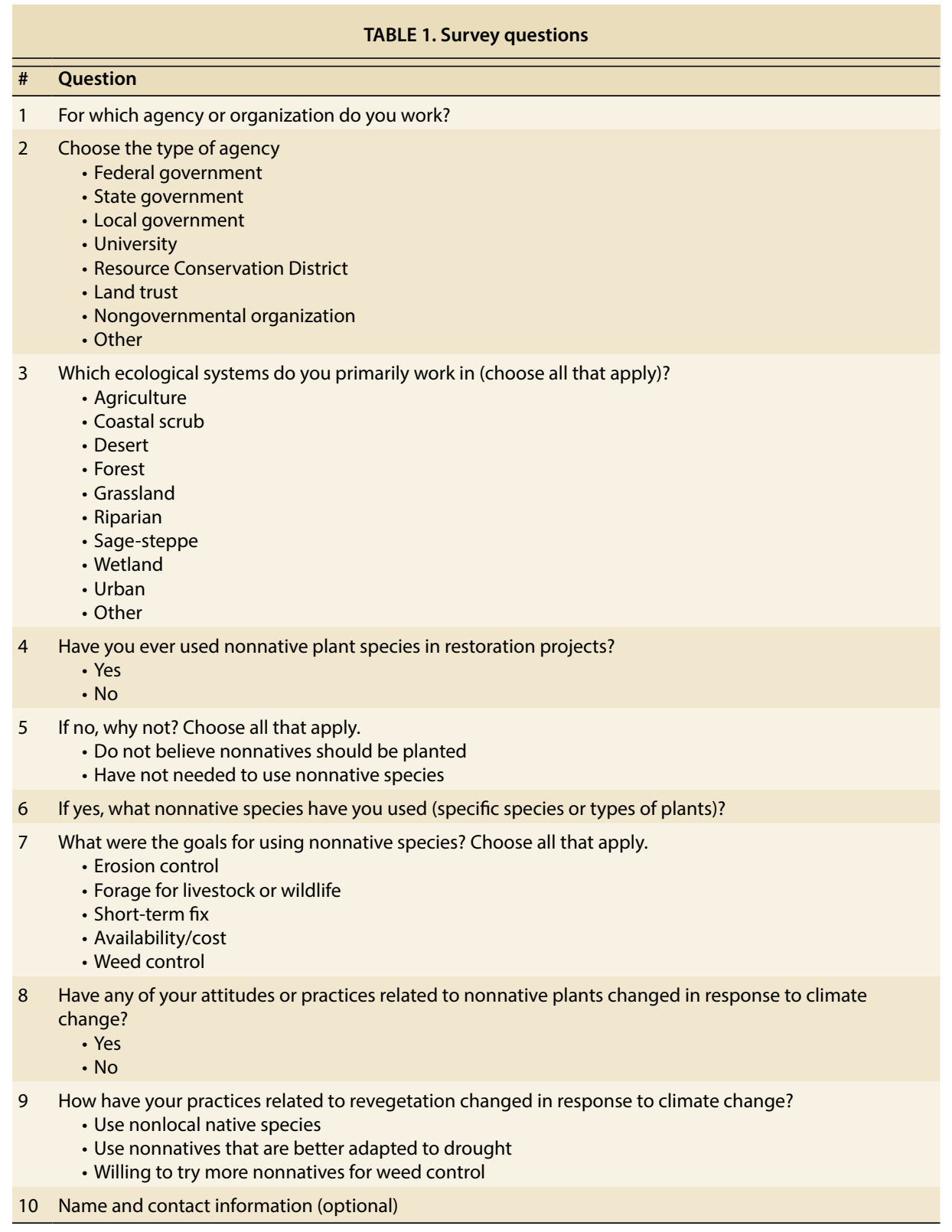

Ecological Restoration (SERCAL, 745 LinkedIn members) and the Society of Wetland Scientists Western Chapter (55 LinkedIn members). We distributed to these groups because they are some of the largest and most longstanding regional societies in California with a cultivated membership characteristic of our target audience. Membership in these groups is disproportionately composed of organizations involved in land management and government agencies, and, as a result, these organizations and agencies are represented disproportionately in the survey data.

Previous surveys deployed by the California Invasive Plant Council using the same approach elicited high response rates from a targeted population (Cal-IPC 2015). In the directions accompanying the survey, we requested that individuals fill out the survey only once, but we had no method to ensure that they did so. We closed the survey on Sept. 4, 2015. We received 192 responses, for an approximate response rate of $17 \%$ (there is overlap among members in the contact groups).

\section{Analysis of survey data}

To address sampling bias, all data were weighted proportionally to a globally derived group of affiliations based on our sampling lists (Maletta 2007). To simplify data for analysis, we organized organizational affiliations into more general 
groups. Survey responses from federal agencies (e.g., Bureau of Land Management [BLM], U.S. Fish and Wildlife Service, and U.S. National Park Service) were grouped into a federal category, state agencies (e.g., California Department of Water Resources, California Department of Food and Agriculture, and California State Parks) were grouped into a state category and local agencies (e.g., resource conservation districts, county agricultural commissioners' offices, and county departments of parks and recreation) were grouped into a local category. Private firms (e.g., for-profit restoration companies and for-profit consultants) were grouped into a private category, nonprofit organizations (e.g., land trusts, the Nature Conservancy, Audubon) were grouped into an NGO category and academic affiliations (e.g., colleges and universities, university-affiliated research reserves and UC Cooperative Extension) were grouped into a university category.

We also grouped habitat types to address unbalanced representation across systems. Where appropriate, habitat types that were represented by a very small number of $(<10)$ respondents were grouped with habitat types that shared major abiotic characteristics. For example, vernal pools were grouped with wetlands, sage-steppe and chaparral were grouped together, coastal dune and coastal scrub were grouped together, and oak woodlands were grouped with grasslands.

Using $R$ version 3.2.0, we employed Pearson's chi-square tests to identify significant differences in (1) the use of nonnative species for revegetation among organizational types and (2) the role of climate change in modifying perspectives on using nonnative species in revegetation. Formal statistical analyses were not used on questions related to the use of nonnative species for revegetation in different habitat types or on questions about the goals for using nonnative species for revegetation because respondents were able to choose more than one habitat type and goal, violating chi-square assumptions of random independent trials.

\section{Survey responses}

Survey responses were dominated by individuals associated with government (but not necessarily regulatory) agencies at the federal $(31 \%$, 61 respondents), state
$(10 \%, 19)$ and local $(11 \%, 22)$ levels (fig. 1). Of the remaining respondents, $3 \%$ (5) were from land trusts, $19 \%$ (37) from other NGOs, $17 \%$ (32) from university affiliations and UC Cooperative Extension, and 9\% (17) from private firms.

We did not ask respondents for their geographic location, but the organizations listed cover at least 25 of the 58 counties in California. We asked respondents to categorize the ecological system in which they worked (fig. 2). The most common habitat types given were grassland $(71 \%)$ and riparian $(68 \%)$, followed by wetland $(45 \%)$, forest (35\%), coastal scrub (32\%) and desert (19\%). Other habitat types listed included sage-steppe (5\%), oak woodland (4\%), chaparral $(4 \%)$, agriculture $(3 \%)$, dunes/estuarine (2\%), vernal pool ( $1 \%)$, open aquatic system (1\%) and urban $(1 \%)$. Most respondents (76\%) noted that they worked in multiple habitat types.

Of the total respondents, $42 \%$ (80) said that they currently used or in the past had used nonnative species for revegetation. There were significant differences across affiliations (fig. $1 ; \chi^{2}=33.90, p<0.001$ ): While a majority of federal agency respondents (67\%) used nonnative species for revegetation, only $39 \%$ of respondents from state agencies and $26 \%$ of respondents from local agencies used nonnative species for revegetation. Respondents from NGOs and private firms were less likely to use nonnatives $(17 \%$ of $\mathrm{NGO}$ respondents and $19 \%$ of respondents in private firms). Half of respondents from university affiliations used nonnative species for revegetation.

There appeared to be differences in the use of nonnative species for revegetation across habitats (fig. 2), from a high of $55 \%$ in desert habitats to a low of $27 \%$ in coastal scrub. Of those who did not use nonnative species, 55\% (62) stated that they were not comfortable with the use of nonnative species for planting and seeding projects; $52 \%$ (58) stated that they had not needed to use nonnative species and 5\% (6) noted that they did not use nonnative species as a matter of formally mandated policy at their place of work (responders were able to identify more than one reason).

Across habitat types, there did not appear to be a difference in the factors that motivated the use of nonnative species for revegetation (fig. 3). For most of the habitats listed (agriculture, coastal scrub, forest, grassland, riparian, sage-steppe, urban and wetland), erosion control was the top or among the top goals cited for the use of nonnative species in revegetation. The exception was desert systems, in which forage was the top motivating factor (fig. 3).

Lastly, 37\% (70) of all respondents noted that their attitudes or practices related to nonnative plants for revegetation had changed in response to climate

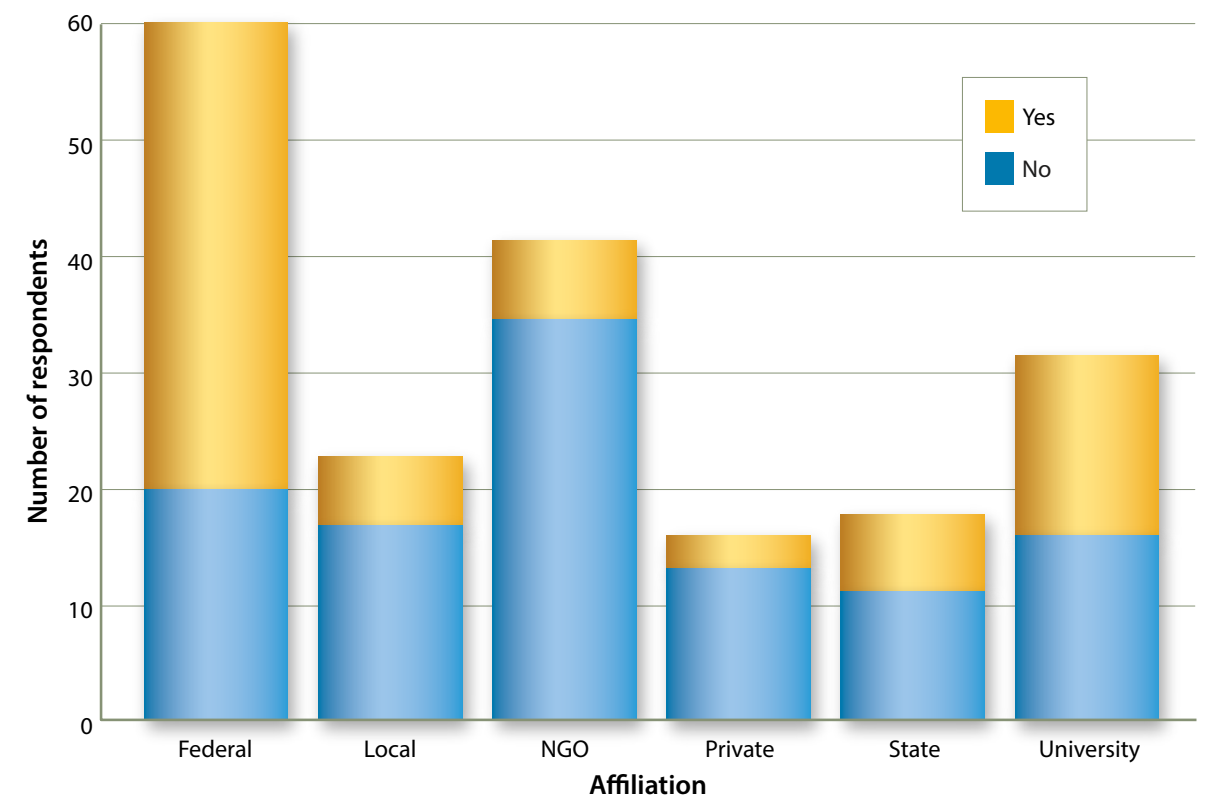

Fig. 1. Number of respondents, by agency, who used/did not use nonnative species for revegetation projects. 
change (data not shown). These attitudes were unaffected by current use of nonnative plants in revegetation $\left(\chi^{2}=0.11\right.$, $p=0.742)$ or affiliation $\left(\chi^{2}=8.58, p=0.127\right)$. Thirty of these individuals stated that they would consider using native plant materials from geographically nonlocal sources, while 24 noted that they would consider using nonnative species that are better adapted to climate change.

\section{Nonnatives review}

The majority of practitioners surveyed in this study did not consider using nonnative plant species for revegetation projects within California, an apprehension likely due in part to historical revegetation efforts that resulted in unintended ecological harm - for example, Tamarix spp. escaping U.S. Department of Agriculture bank stabilization projects to become noxious weeds in the West (Hultine et al. 2010). More than half of these respondents noted that they did not need to use nonnative species for revegetation. Their fill-in responses highlighted the utility of hybrids and varieties of natives to develop a high-diversity mix that proves beneficial for achieving revegetation goals.

Government agencies were more likely to use nonnative species for revegetation projects than other organizations (excluding university affiliates). This could be a result of a difference in revegetation goals. On lands managed for multiple use objectives, including grazing, revegetation goals may emphasize increasing forage production and palatability, and not necessarily include increasing native plant biodiversity. Revegetation goals on other lands may emphasize re-establishing functional plant communities that match an ecological reference site.

Despite a history of negative ecological consequences of using nonnative species for revegetation in the West (e.g., Cable 1971; Gray and Muir 2013), almost half of the practitioners surveyed indicated that they have used nonnative species for revegetation projects, suggesting that from the perspective of a practitioner the potential benefits of nonnative species can outweigh the ecological risks. Of the respondents who indicated that they did consider nonnative species for restoration, erosion control was the top motivator across habitat types. Erosion control, especially early in a restoration project, can enhance stability to subsequently resist invasive species spread and allow for the establishment and persistence of native species (Morris and Schupp 2009). Species highlighted in the fill-in section as commonly used for erosion control primarily included annual grasses, such as rye, barley, orchardgrass, and in some cases perennial grasses, such as wheatgrass (crested, intermediate and Siberian).

In some cases, nonnative species have proven utility for rehabilitation due to their adaptability, high establishment rates and low-cost availability (e.g., Richards et al. 1998). Indeed, respondents commonly mentioned the high cost of native plant material and the unavailability of many needed species, which has been discussed elsewhere (Török et al. 2011). However, the importance of maintaining and re-establishing native biodiversity is widely recognized.

One way to enhance widespread use of native species for revegetation projects is to expand the availability of native plant

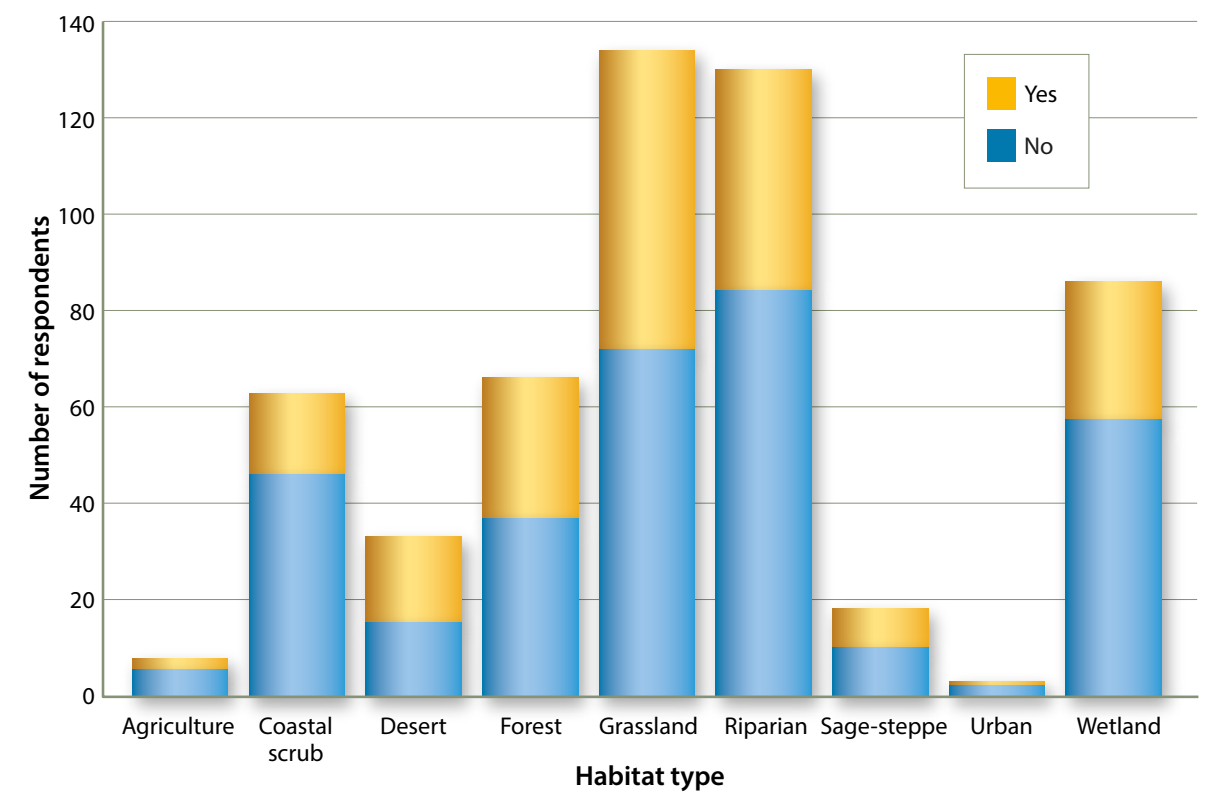

Fig. 2. Number of respondents, by habitat type, who used/did not use nonnative species for revegetation projects.

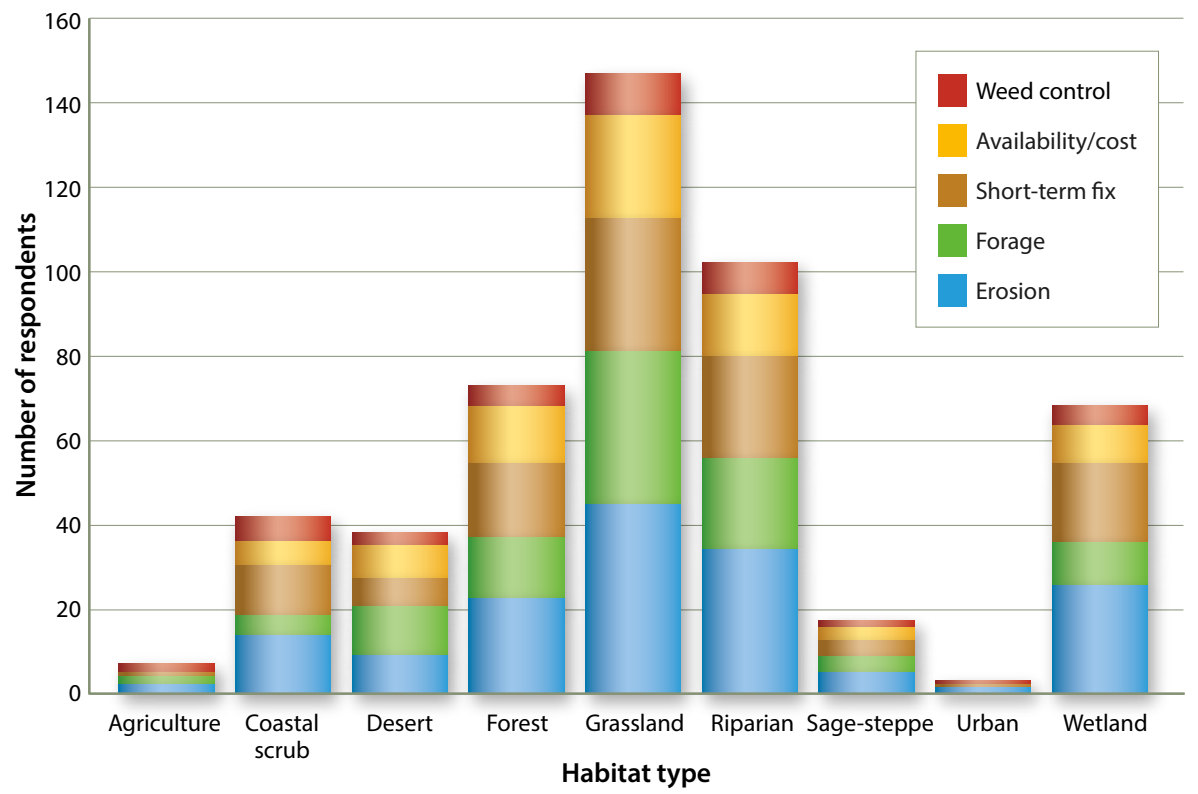

Fig 3. Goals, by system, for using nonnative species for revegetation. Respondents were able to indicate more than one motivation per system. 
materials at a reasonable cost. Currently, many groups, such as the nursery industry, private organizations and government agencies, are making strides to expand the availability of natives (e.g., BLM's National Seed Strategy). Moreover, given that the top motivation for using nonnative species is erosion control, researchers might focus on identifying native plants with traits that enhance soil stability, such as rapid establishment and considerable root structure.

The relatively large portion (37\%) of respondents who noted they had changed their perspective and practices related to nonnatives as a result of climate change highlights an important dynamic to be considered by both researchers and practitioners. As reliance on nonlocal and nonnative plant materials increases, continued research investigating the relationship between climate change and invasive plants (e.g., Hellmann et al. 2008) is imperative. It is needed to provide high-confidence predictions of the spread and impact of invasive species, which will help practitioners design effective revegetation strategies.

For their part, practitioners can request from native nurseries the seed collection and mass production of native species with traits that confer resilience to drought. Researchers in academia can take the lead on conducting greenhouse and field experiments that identify fruitful revegetation candidates. Cooperation among the entire network of stakeholders associated with restoration will result in more effective strategies for land managers designing and deploying revegetation projects that accommodate the effects of climate change.
Exploring the use of nonnative species in revegetation involves accepting, philosophically, the role of nonnative plants in ecosystems, and it involves practical considerations, such as project objectives and plant availability and cost. This survey illuminates current practices of those working in restoration in California, and these data will support further discussion about the role of nonnative plants in restoration. CA

\section{E. Gornish is UC Cooperative Extension Specialist in the Department of Plant Sciences at UC Davis; E. Brusati was Senior Scientist at California Invasive Plant Council and currently is at California Department of Fish and Wildlife, Sacramento; D.W. Johnson is Executive Director at California Invasive Plant Council, Berkeley.}

\section{References}

Allen EB, Cox RD, Tennant T, et al. 2005. Landscape restoration in southern California forblands: Response of abandoned farmland to invasive annual grass control. Israel J Plant Sci 53:237-45.

Asay KH, Johnson DA. 1983. Genetic variability for charac ters affecting stand establishment in crested wheatgrass. J Range Manage 36:703-6.

Brodt S, Klonsky K, Jackson L, et al. 2009. Factors affecting adoption of hedgerows and other biodiversity-enhancing features on farms in California USA. Agroforest Syst 76:185-206.

Bullock JM, Aronson J, Newton AC, et al. 2011. Restoration of ecosystem services and biodiversity: Conflicts and opportunities. Trends Ecol Evolut 26:541-9.

Cable DR. 1971. Lehmann lovegrass on the Santa Rita experimental range, 1937-1968. J Range Manage 24:17-21.

Cal-IPC. 2015. Best Management Practices for Wildland Stewardship: Protecting Wildlife When Using Herbicides for Invasive Plant Management. Cal-IPC Publication 2015 1. California Invasive Plant Council, Berkeley, CA.

Carroll SP. 2011. Conciliation biology: The eco-evolutionary management of permanently invaded biotic systems Evol Appl 4:184-99.

Clewell A, Rieger JP. 1997. What practitioners need from restoration ecologists. Restor Ecol 5:350-4.

D'Antonio C, Meyerson L. 2002. Exotic plant species as problems and solutions in ecological restoration: A synthesis. Restor Ecol 10:703-13.

Davies KW, Boyd CS, Johnson DD, et al. 2015. Success of seeding native compared with introduced perennial vegetation for revegetating medusahead-invaded sagebrush rangeland. Rangeland Ecol Manag 68:224-30.

Davies KW, Boyd CS, Nafus AM. 2013. Restoring the sagebrush component in crested wheatgrass-dominated communities. Rangeland Ecol Manag 66:472-8.

Davies KW, Nafus AM, Sheley RL. 2010. Nonnative competitive perennial grass impedes the spread of an invasive annual grass. Biol Invasions 12:3187-94.

Davison J, Smith E. 1996. Crested wheatgrass: Hero or villain in reclaiming disturbed rangelands. University of Nevada Cooperative Extension Fact Sheet 96-53. www. unce.unr.edu/publications/files/nr/other/fs9653.pdf.
DiTomaso JM, Healy EA. 2007. Weeds of California and Other Western States. Oakland, CA: UC ANR. 1,808 p.

Egan D, Howell EA. 2001. The Historical Ecology Handbook: A Restorationist's Guide to Reference Ecosystems. Washington, DC: Island Press.

Eviner VT, Garbach K, Baty JH, Hoskinson SA. 2012. Measuring the effects of invasive plants on ecosystem services: Challenges and prospects. Invasive Plant Sci Manag 5:125-36.

Ewel JJ, Putz FE. 2004. A place for alien species in ecosystem restoration. Front Ecol Environ 2:354-60.

Gornish ES. 2015. An extension perspective on California grassland restoration. Grasslands 25:6-8.

Gray EC, Muir PS. 2013. Does Kochia prostrata spread from seeded sites? An evaluation from southwestern Idaho, USA. Rangeland Ecol Manag 66:191-203.

Harris JA, Hobbs RJ, Higgs E, Aronson J. 2006. Ecological restoration and global climate change. Restor Ecol 14:170-6.

Hellmann JJ, Byers JE, Bierwagen BG, Dukes JS. 2008. Five potential consequences of climate change for invasive species. Conserv Biol 22:534-43.

Herget ME, Hufford KM, Mummer DL, et al. 2015. Effects of competition with Bromus tectorum on early establishment of Poa secunda accessions: Can seed source impact restoration success? Restor Ecol 23:277-83.

Hobbs RJ, Arico S, Aronson J, et al. 2006. Novel ecosystems: Theoretical and management aspects of the new ecological world order. Global Ecol Biogeogr 15:1-7.

Hobbs RJ, Higgs E, Harris JA. 2009. Novel ecosystems: Implications for conservation and restoration. Trends Ecol Evolut 24:599-605.

Hultine KR, Belknap J, van Riper III C, et al. 2010. Tamarisk biocontrol in the western United States: Ecological and societal implications. Front Ecol Environ 8:467-74.

Kondolf GM, Anderson S, Lave R, et al. 2007. Two decades of river restoration in California: What can we learn? Restor Ecol 15:516-23.

Maletta H. 2007. Weighting. www.spsstools.net/static/ resources/WEIGHTING.pdf.
Meli P, Martinez-Ramos M, Rey-Benayas JM, Carabias J. 2014. Combining ecological, social and technical criteria to select species for forest restoration. Appl Veg Sci 17:744-53.

Monsen SB. 2004. History of range and wildlife habitat restoration in the Intermountain West. In: Monsen SB, Stevens R, Shaw NL (compilers). Restoring Western Ranges and Wildlands. General Technical Report RMRS-GTR-136vol-1. USDA Forest Service, Rocky Mountain Research Station, Fort Collins, Colorado.

Morris C, Schupp EW. 2009. Comparison of emergence speed and sterility in two sterile annual hybrid cereal grasses developed for use in restoration. Restor Ecol 17:678-85.

Pyke DA, Wirth TA, Beyers JL. 2013. Does seeding after wildfires in rangelands reduce erosion or invasive species? Restor Ecol 21:415-21.

Richards RT, Chambers JC, Ross C. 1998. Use of native plants on federal lands: Policy and practice. J Range Manage 51:625-32.

Rodriguez LF. 2006. Can invasive species facilitate native species? Evidence of how, when, and why these impacts occur. Biol Invasions 8:927-39.

[SER] Society for Ecological Restoration International Science \& Policy Working Group. 2004. The SER International Primer on Ecological Restoration. www.ser.org and Tucson: Society for Ecological Restoration International.

Stanturf JA, Schoenholtz SH, Schweitzer C, Shepard SP. 2001. Achieving restoration success: Myths in bottomland hardwood forests. Restor Ecol 9:189-200.

Stromberg MR, Griffin JR. 1996. Long-term patterns in coastal California grasslands in relation to cultivation, gophers, and grazing. Ecol Appl 6:1189-211.

Stylinski CD, Allen EB. 1999. Lack of native species recovery following severe exotic disturbance in southern California shrublands. J Appl Ecol 36:544-54.

Török P, Vida E, Deák B, et al. 2011. Grassland restoration on former croplands in Europe: An assessment of applicability of techniques and costs. Biodivers Conserv 20:2311-32.

Vasey MC, Holl KD. 2007. Ecological restoration in California: Challenges and prospects. Madroño 54:215-24. 